"Determinants of viability in junior mining companies in the Witbank region of South Africa"

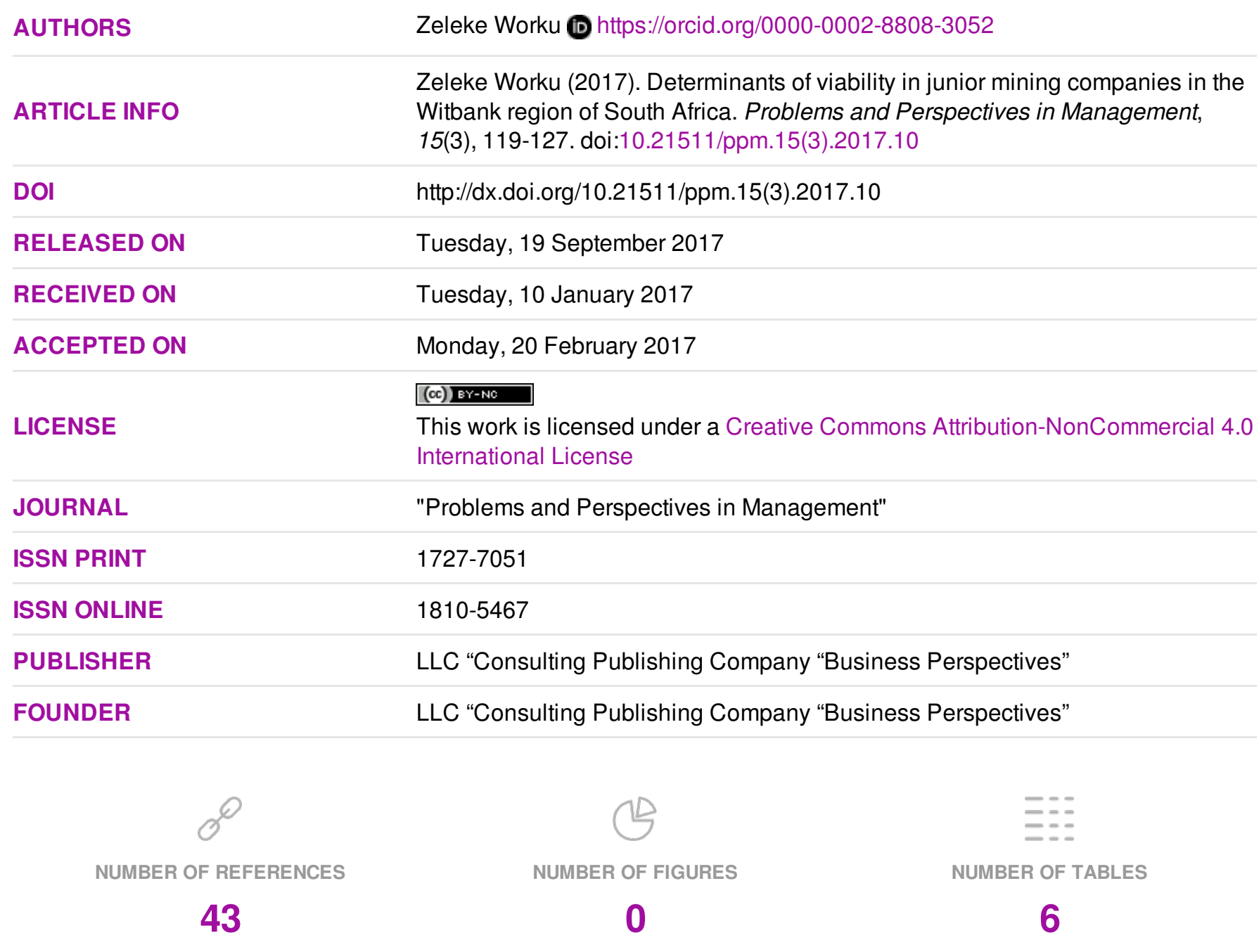

(C) The author(s) 2023. This publication is an open access article. 


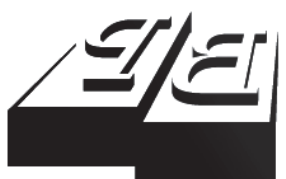

BUSINESS PERSPECTIVES

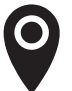

LLC "CPC "Business Perspectives" Hryhorii Skovoroda lane, 10, Sumy, 40022, Ukraine

www.businessperspectives.org

Received on: $10^{\text {th }}$ of January 2017 Accepted on: $20^{\text {th }}$ of February2017

(c) Zeleke Worku, 2017

Zeleke Worku, Tshwane University of Technology (TUT) Business School, South Africa

\title{
DETERMINANTS OF VIABILITY IN JUNIOR MINING COMPANIES IN THE WITBANK REGION OF SOUTH AFRICA
}

\begin{abstract}
An exploratory survey was undertaken in order to explore the underlying causes of bankruptcy in junior mining companies operating in the Witbank region of Mpumalanga Province based on data gathered from 120 highly experienced employees of junior mining companies operating at Witbank. Perception on barriers to productivity in junior mines was measured based on a scale introduced by Henisz, Dorobantu and Nartey (2014). Data was gathered on 24 socioeconomic variables. Data was analysed by performing logit analysis. The key finding of study was that $74.17 \%$ of respondents believed that their mines were profitable and productive. Productivity of mines was found to be undermined high cost of transport [OR $=4.51 ; \mathrm{P}=0.003 ; 95 \% \mathrm{CI}=$ $(2.26,7.58)]$, low demand for mine products $[\mathrm{OR}=2.65 ; \mathrm{P}=0.009 ; 95 \% \mathrm{CI}=(1.86$, $6.14)]$ and inability to improve the public images of junior mining companies [OR = $2.53 ; \mathrm{P}=0.015 ; 95 \% \mathrm{CI}=(1.80,5.76)]$.
\end{abstract}

Keywords Junior mines, Witbank, Viability, Productivity, Logit analysis

JEL Classification D2, O47, O49

\section{INTRODUCTION}

An exploratory survey was carried out at the Witbank region of Mpumalanga Province by collecting data on the perception held by 120 highly experienced experts who have been working in the mineral processing industry for several years. The expected output of survey was to find out why a large number of junior mining companies were out of production, and to seek appropriate remedial measures. The research was carried out at a time of falling demand for commodities produced by mines at local and global levels as well as an increase in the number of small mining enterprises closing down operation due to various socioeconomic reasons.

According to Anderson, Asdemir and Tripathy (2012, p. 649) and Le Pla (2009, p. 28), junior mining companies must explore innovative ways and means of reducing operational cost in order to stay profitable. Shank, Lawler and Carr $(2015$, p. 41) have carefully analysed the internal value chain of the mining sector of the economy, and have reported that a company might discover that economic profits are carried in downstream activities such as distribution or customer service, but not in upstream activities in basic mining or processing. According to Buckley and Ghauri (2012), the ability to operate cost-effectively and the degree of utilization of innovative methods of mining, production, marketing and sale of com- 
modities are vital to stay in business. The authors have pointed out that the demand for commodities in China has reduced. Following the falling demand for commodities in China, junior mining companies have suffered a huge loss in revenue. There is no hope of this situation changing at least in the near future, hence the need for junior miners to look at strategies of cutting costs. The study aims to assess the degree of relevance and potential benefit of various cost cutting strategies used by junior mining companies operating at the Witbank region of Mpumalanga Province.

The study was conducted in an attempt to shade light on the worsening economic plight of junior mines operating in the Witbank region. The region is fraught with massive unemployment, lack of infrastructure and environmental pollution arising from mining activities. Junior mines provide employment opportunities to graduates of high schools and educational institutions operating in the region. There is a significant lack of vocational and specialist skills that among the youth. Employment opportunities are scarce. The South African Small Enterprises Development Agency (SEDA, 2016) provides assistance to novice entrepreneurs by way of rolling out training and mentorship programmes to various economic sectors including the mining sector. Annual reports issued by the South African Chamber of Mines (2016) and Statistics South Africa (2016) indicate that the Witbank region is characterised by unemployment, environmental pollution and lack of direct investment. Experiential and vocational training opportunities are scarce in the Witbank region. The problem of environmental pollution arising from industrial and mining activities undermine the overall health condition of the population living in and around Witbank. Workplace training opportunities could be used for improving the degree of skills possessed by young people. The study conducted by Achrya, Lochstoer and Ramadorai (2013) has shown that workplace training has numerous benefits to junior mines.

Junior mines could use workplace training as a means to improve the degree of tailor-made vocational and artisan skills among workers who lack such skills at the workplace. Workplace training must be relevant to the KPAs and KPIs of employees in order to be effective. This is because any workplace training must be of high quality and relevance to the operations that are carried out at the workplace. Workplace training entails dedication and the availability of resources such as training budget, money for trainers and venues for training. Junior mines often need to cut down operational cost in order to make profit. This means that junior mines are required to attract highly skilled and dedicated employees although they are unable to pay them attractive salaries. Junior mines are also required by law to adhere to the South African Labour Relations Act of 1996 (South African National Department of Labour, 1996) at the workplace. In an attempt to ensure productivity and quality production, junior mines are required to balance operational needs with effective incentives for employees with vital skills. Apprenticeship is a typical model used for ensuring the retention and development of specialised skills in junior mines. It requires the availability of resources such as money, trainers with proven skills and economic incentives to young trainees. Apprenticeship is not always affordable to junior mines. This is because it requires employers to provide employees with economic incentives such as basic income, decent working conditions and insurance cover. As a result, junior mines fail to utilise and benefit from apprenticeship.

\section{BACKGROUND}

Junior mining enterprises lack the resources for competing with large mining enterprises for various reasons. They have limited access to local and international markets. They are often required to abide by legislation that applies to large and adequately resourced mining companies. They are constrained by acute shortage of finance and inability to secure loan. They are also obliged to abide by the Labour Relations Act of 1996. In an attempt to ensure viability and profitability, junior mines are constantly required to look for innovative methods of saving operational cost. They are also required to utilise modern technological methods of operation, production, mineral processing and marketing. They have limited access to local and international markets. The tax burden on emerging mines is a major obstacle to profitability in the sector. Often, the tax assessment made on junior mines is unfair, and fails to take into account missed economic opportunities at 
local and international levels, lack of access to lucrative global markets, the acute shortage of vocational and artisan skills, intense competition from well-established and large mining companies, labour unrest and economic downturn. The study conducted by Barney (2012) has shown that large organizations can easily improve their overall productivity by using innovative methods such as workplace training and skills based short courses for their middle level managers and team leaders. Bhatt \& Grover (2013) have pointed out that it is possible to improve productivity by utilizing on-the-job training and tailor-made short learning programmes for employees working in small enterprises.

\section{LITERATURE REVIEW}

The Witbank region is home to a large number of junior mineral processing companies that operate as private enterprises in the South African mining industry. Small mining enterprises at Witbank currently experience developmental challenges. A few examples of such challenges are inability to raise money, shortage of specialised and technical skills, poor demand for commodities in local and global markets, high labour cost, stringent labour conditions and legislation, lack of access to local and global markets, intense competition from large mining enterprises, high tax, high cost of electricity and transpiration and high insurance cost. The study was conducted against the need to assess and evaluate the views held by the experts on major causes of underperformance and bankruptcy in the mineral processing industry. Very few studies have been conducted to date in the junior mining sector of Witbank about socioeconomic factors that adversely affect overall productivity and operational cost and the potential benefits of providing tailor-made workplace training opportunities to employees. Workplace training opportunities are vital for employees of small mining enterprises based on assessments made in the past several years by the South African National Department of Public Service and Administration (2016), Achrya, Philippon, Richardson and Roubini (2009) and Bagozzi (2007).

A typical feature of South African small mining enterprises is shortage of vocational and special- ized skills, lack of access to finance by formal money lending institutions, high cost of labour, high cost of transportation, poor access to local and global markets, high tax and lack of incentives to productive and loyal employees. The potential benefits of workplace training programmes to workers employed by small mining enterprises have been outlined by Adams and Mehran (2003), Amit and Schoemaker (2013), Beck and DemirgucKunt (2013), Benjamin, Andreas and Ramon (2012), Bharadwaj (2013) and Beetsma, Giuliodori, De Jong and Widijanto (2013).

Studies conducted by risk specialists such as Prahalad and Hamel (2014) and Beck and Demirguc-Kunt (2012) have shown that workplace training opportunities are vital for improving overall productivity in small mining enterprises. A similar assessment has been made by Fahy (2013) and Elliot and Bischoff (2013).

Katzenbach and Bromfield (2009, p. 14-15) have shown that the following factors are helpful for reducing operational cost in small mining enterprises:

- Ensuring overall efficiency by avoiding duplicate processes and work structures.

- Motivating and incentivising workers by focusing on individual aims and aspirations of employees.

- The provision of skills based and tailormade training opportunities on a regular basis.

- Exploring external opportunities as a means of broadening the clientelle base in the market.

Sovacool, Sidortsov and Jones (2013) have proposed the Action-Profit Linkage Model for small and newly established enterprises in developing nations. The Action-Profit Linkage Model is a framework that is vital for streamlining activities in such a way that duplicate efforts are removed and the utilization of resources is optimised. Sovacool and Cooper (2013) have shown that rationalising and optimising resources is critically vital for performing at full potential in newly 
established enterprises such as small minming companies. Outsourcing is commonly used as a cost-cutting measure. However, using outsourcing for the wrong reasons could result in the loss of vital skills and expertise (Costa \& Beaumont, 2001, p. 5-6). Ladzani and Seeletse (2012, p. 88) have reported similar findings based on research conducted in various emerging small, micro and mediumsized enterprises in Gauteng Province, South Africa.

The mining industry is central to the South African economy. The current decrease in commodity price has triggered a flood of disinvestment in the mining industry. The key losers have been small mines. A review of the literature shows that each mine needs a tailor-made solution and strategy for cost saving and enhancement of overall productivity. Solutions that have produced results in large mining companies are not necessarily feasible in small mining companies. There is a need for tailor-made solutions that could work in small companies. The specific objectives of study were to identify and quantify factors that affect productivity at junior mining companies.

Workplace training is defined by Nel, Werner, Poisat, Sono Du Plessis and Ngalo (2011) as an innovative and cost effective tool to develop the overall productivity of employees. It is directed at improving employee's job performance and brings about required behavioural changes to meet the organisational goals. The benefits of training are but not limited to, improving job knowledge and skills at all levels of the organisation, assist in developing leadership skills, assist in increasing productivity or quality of work and to reduce external consulting costs by utilising competent internal consulting. There are various training deliveries and approaches.

According to Dashwood (2014, p. 551-582), Henderson, Pearson and Wang (2014) and Du Plessis, Van Niekerk (2014, p. 1-12), ensuring the mastery of technical skills at global standards is a critical requirement for financial sustainability in enterprises such as small mineral processors. The study conducted by Acharya, Lochstoer and Ramadorai (2013, p. 441-465) has shown that commodity markets are most vulnerable to low demand. Cheng, Kirilenko and Xiong (2015, p. 1733-1781) have shown that the price of commodities such as mineral products requires the highest standards of innovative skills in order for junior mining enterprises that produce the products to stay competitive in the global market. Workplace training could be offered by using methods such as coaching and one-to-one instruction as a means of transferring knowledge and skills from a more experienced person to someone else who needs to improve the current degree of knowledge and overall productivity. Job rotation entails staff being transferred from job to job on a systematic basis, thus creating greater flexibility and skills within a team (Cheng \& Xiong, 2014 , p. 419-441). Duffie (2010, p. 1237-1267) has reported that the price of mineral products varies depending on the quality and innovative technology used for producing the finished products.

There are numerous socioeconomic, demographic and political factors that affect growth and development in the mining sector. Spreng $(2014$, p. $65-$ 73) and Harris (2011, p. 101-109), the biggest factors that affect sustained growth in the South African mining sector are high cost of labour, inflexible labour laws, too much bureaucracy, red tape, lack of efficient municipal services, high cost of energy, high cost of transport and heavy equipment, lack of technical skills that are needed for ensuring profitable mining operation, labour unrest, the vertical depth of mines, shortage of technology needed for extracting mines from deep deposits, lack of reliable policy on the mining sector, inability to reduce unemployment and poverty levels among the majority population group, lack of good governance, failure to adhere to regulations and guidelines, lack of leadership, and policy-related uncertainty about the mining sector of the economy. Surveys conducted by Deloitte (2016) and Sidortsov (2014, p. 171-182) have found that the arduous task of addressing environmental pollution that has been caused by mining operations that were carried out in the past several decades is a costly and logistically challenging exercise. South Africa relies on the mining sector for ensuring sustained economic growth and development. The cost of commodities has been decreasing over the past several years. Since the early 1970s, South African mines have become deeper, less profitale and much more dangerous than they were a hundred years ago. As a result, mining operations in South Africa have become less profitable at the moment. 


\section{OBJECTIVE OF STUDY}

The aim of the research was to assess and evaluate the underlying causes of lack of profitability and productivity in junior mining companies operating at the Witbank region of Mpumalanga Province. The specific objectives of study are to identify and quantify factors that affect productivity at the mining company. The study aims to assess the perception held by employees on ways and means of reducing operational cost and boosting overall production and profitability at junior mining companies operating at the Witbank region of Mpumalanga Province. The research had four specific aims:

- To assess and evaluate the perception held by employees of junior mining companies operating at the Witbank region of Mpumalanga Province about factors that undermine overall productivity and viability in the junior mining enterprise.

- To assess the degree to which employees of junior mining companies operating at the Witbank region of Mpumalanga Province could benefit from the roll out of training programmes.

- To identify suitable and affordable economic incentives that could be provided to employees of junior mining companies operating at the Witbank region of Mpumalanga Province as a means of boosting morale and workplace productivity.

\section{METHODS AND MATERIALS OF STUDY}

Data was collected from 120 employees of junior mining enterprises operating at Witbank on various socioeconomic factors that undermine profitability and productivity in junior mining enterprises. Perception was measured by using a scale defined by Henisz, Dorobantu and Nartey (2014). Analyses of data were performed by using univariate and bivariate methods (Hair, Black, Babin, \& Anderson, 2010) and logit regression (Hosmer \& Lemeshow, 2015).

\section{RESULTS OF DATA ANALYSES}

Table 1 presents numbers and frequency percentages for the general socioeconomic characteristics of respondents.

It can be seen from Table 1 that $74.17 \%$ of the 120 junior mines selected for the study were viable, whereas the remaining $25.83 \%$ were not viable. The table shows that nearly $68 \%$ of respondents had the perception that viability and overall productivity was undermined due to bureaucratic regulations and red tape.

Table 2 shows frequency proportions and percentages for the perceptions held by the 120 respondents of study on factors that undermine overall productivity and profitability at their company. The table shows that nearly $77 \%$ of respondents had difficulty in ordering or securing stock from suppliers. High cost of labour was perceived as a key barrier to sustained growth, viability and productivity by $84.17 \%$ of respondents. High cost of transportation was seen as a barrier to viability by $88.33 \%$ of respondents. Nearly $67 \%$ of respondents viewed high cost of maintenance as a barrier to viability.

Table 3 shows frequency proportions and percentages for the perceptions held by the 120 respondents of study on the benefits of outsourcing to overall productivity and profitability at their company. The table shows that about $60 \%$ of respondents agree that that outsourcing is helpful for improving overall productivity and viability in their mining enterprises. The table also shows that about $82 \%$ of respondents believe that using original equipment manufacturers on a contractual basis is beneficial to their companies.

Table 4 shows frequency proportions and percentages for the perceptions held by the 120 respondents of study on the degree to which sales growth and improved market share have been realised in their companies over the past several years. It can be seen from the table that about $93 \%$ of respondents believe that their companies have achieved growth in sales in the past several years of operation. The table shows that about $83 \%$ of respondents believe that their companies have achieved 
Table 1. General characteristics of respondents $(n=120)$

\begin{tabular}{|c|c|}
\hline Variable of study & Percentage \\
\hline Perception on viability of company & $\begin{array}{l}\text { Viable: } 89(74.17 \%) \\
\text { Not viable: } 31(25.83 \%)\end{array}$ \\
\hline Type of mining enterprise & $\begin{array}{l}\text { Joint venture: } 14(11.67 \%) \\
\text { Partnership: } 23(19.17 \%) \\
\text { Private company: } 26(21.67 \%) \\
\text { Sole ownership: } 54(45.00 \%) \\
\text { Others: } 3(2.50 \%)\end{array}$ \\
\hline Main activity of company & $\begin{array}{l}\text { Full value chain: } 7(5.83 \%) \\
\text { Mining: } 42(35.00 \%) \\
\text { Processing: } 59(49.17 \%) \\
\text { Trading: } 12(10.00 \%)\end{array}$ \\
\hline Size of company in millions of Rand & $\begin{array}{l}\text { Above } 200: 29(24.17 \%) \\
151 \text { to } 200: 15(12.50 \%) \\
101 \text { to } 150: 21(17.50 \%) \\
81 \text { to } 100: 13(10.83 \%) \\
80 \text { or less: } 42(35.00 \%)\end{array}$ \\
\hline Number of employees in company & $\begin{array}{l}21 \text { or more: } 25(20.83 \%) \\
16 \text { to } 20: 70(58.33 \%) \\
9 \text { to } 15: 9(7.50 \%) \\
8 \text { or less: } 16(13.33 \%)\end{array}$ \\
\hline Viability undermined by failure to secure loan needed for operation & $\begin{array}{l}\text { Yes: } 54(45.00 \%) \\
\text { No: } 66(55.00 \%)\end{array}$ \\
\hline Viability undermined due to intense competition from well-established mining enterprises & $\begin{array}{l}\text { Yes: } 79(65.83 \%) \\
\text { No: } 41(34.17 \%)\end{array}$ \\
\hline Viability undermined due to low demand for products at the marketplace & $\begin{array}{l}\text { Yes: } 100(83.33 \%) \\
\text { No: } 20(16.67 \%)\end{array}$ \\
\hline Viability undermined due to unfair tax & $\begin{array}{l}\text { Yes: } 81(67.50 \%) \\
\text { No: } 39(32.50 \%)\end{array}$ \\
\hline Viability undermined due to bureaucratic regulations and red tape & $\begin{array}{l}\text { Yes: } 81(67.50 \%) \\
\text { No: } 39(32.50 \%)\end{array}$ \\
\hline
\end{tabular}

Table 2. Barriers to productivity $(n=120)$

\begin{tabular}{|c|c|}
\hline Variable of study & Percentage \\
\hline Difficulty in ordering or securing stock from suppliers & $\begin{array}{l}\text { Yes: } 92(76.67 \%) \\
\text { No: } 28(23.33 \%)\end{array}$ \\
\hline High cost of labour & $\begin{array}{l}\text { Yes: } 101(84.17 \%) \\
\text { No: } 19(15.83 \%)\end{array}$ \\
\hline High cost of maintenance & $\begin{array}{l}\text { Yes: } 80(66.67 \%) \\
\text { No: } 40(33.33 \%)\end{array}$ \\
\hline High cost of transportation & $\begin{array}{l}\text { Yes: } 106(88.33 \%) \\
\text { No: } 14(11.67 \%)\end{array}$ \\
\hline
\end{tabular}

Table 3. Benefits of outsourcing to productivity $(n=120)$

\begin{tabular}{|c|c|}
\hline Variable of study & Percentage \\
\hline Benefits of outsourcing to overall productivity & $\begin{array}{l}\text { Strongly agree: } 12(10.00 \%) \\
\text { Agree: } 59(49.17 \%) \\
\text { Neutral: } 20(16.67 \%) \\
\text { Disagree: } 28(23.33 \%) \\
\text { Strongly disagree: } 1(0.83 \%)\end{array}$ \\
\hline Benefits of using original equipment manufacturers on a contractual basis & $\begin{array}{l}\text { More than expected: } 14(11.67 \%) \\
\text { As expected: } 84(70.00 \%) \\
\text { Less than expected: } 14(11.67 \%) \\
\text { No benefit at all: } 8(6.67 \%)\end{array}$ \\
\hline
\end{tabular}


Table 4. Assessment of perception on sales growth and market share $(n=120)$

\begin{tabular}{|c|c|}
\hline Variable of study & Percentage \\
\hline $\begin{array}{l}\text { Perception on the degree to which sales growth has been realised over the past several } \\
\text { years }\end{array}$ & $\begin{array}{l}\text { More than expected: } 88(73.95 \%) \\
\text { As expected: } 22(18.49 \%) \\
\text { Less than expected: } 8(6.72 \%) \\
\text { Poor: } 1(0.84 \%) \\
\text { Very poor: } 0(0.00 \%)\end{array}$ \\
\hline $\begin{array}{l}\text { Perception on the degree to which market share has been improved over the past several } \\
\text { years }\end{array}$ & $\begin{array}{l}\text { More than expected: } 71(59.17 \%) \\
\text { As expected: } 27(22.50 \%) \\
\text { Less than expected: } 0(0.00 \%) \\
\text { Poor: } 21(17.50 \%) \\
\text { Very poor: } 1(0.83 \%)\end{array}$ \\
\hline $\begin{array}{l}\text { Perception on the degree to which net profit has been improved over the past several } \\
\text { years }\end{array}$ & $\begin{array}{l}\text { More than expected: } 49(40.83 \%) \\
\text { As expected: } 29(24.17 \%) \\
\text { Less than expected: } 0(0.00 \%) \\
\text { Poor: } 31(25.83 \%) \\
\text { Very poor: } 11(9.17 \%)\end{array}$ \\
\hline $\begin{array}{l}\text { Perception on the degree to which liquidity has been improved over the past several } \\
\text { years }\end{array}$ & $\begin{array}{l}\text { More than expected: } 60(50.00 \%) \\
\text { As expected: } 31(25.83 \%) \\
\text { Less than expected: } 0(0.00 \%) \\
\text { Poor: } 24(20.00 \%) \\
\text { Very poor: } 5(4.17 \%)\end{array}$ \\
\hline $\begin{array}{l}\text { Perception on the degree to which the public image of the company has been improved } \\
\text { over the past several years }\end{array}$ & $\begin{array}{l}\text { More than expected: } 72(60.00 \%) \\
\text { As expected: } 29(24.17 \%) \\
\text { Less than expected: } 0(0.00 \%) \\
\text { Poor: } 15(12.50 \%) \\
\text { Very poor: } 4(3.33 \%)\end{array}$ \\
\hline
\end{tabular}

growth in market share in the past several years of operation. It can be seen from the table that about $65 \%$ of respondents believe that their companies have achieved growth in net profit in the past several years of operation. The table shows that about $76 \%$ of respondents believe that their companies have achieved growth in liquidity in the past several years of operation. The table shows that about $74 \%$ of respondents believe that their companies have achieved improvement in their public image in the past several years of operation.

\subsection{Results from cross-tab analyses}

Table 5 presents results obtained from cross-tab analyses.

\subsection{Results from binary logistic regression analysis}

Table 6 shows estimates from logit analysis.

Table 6. Barriers to profitability of junior mines

\begin{tabular}{l|c:c:c}
\hline \multicolumn{1}{c}{ Barriers to profitability } & $\begin{array}{c}\text { Odds } \\
\text { Ratio }\end{array}$ & P-value & 95\% C. I. \\
\hline High cost of transportation & 4.51 & 0.003 & $(2.23,7.58)$ \\
\hline Low demand for products & 2.65 & 0.009 & $(1.86,6.14)$ \\
\hdashline Failure to improve public image & 2.53 & 0.015 & $(1.80,5.76)$ \\
\hline
\end{tabular}

At the $5 \%$ level of significance, 3 of the 8 variables were found to be key obstacles to profitability in junior mines. These obstacles were high cost of transportation, low demand for products and failure to improve public image.

Table 5. Significant associations obtained from cross-tab analyses

\begin{tabular}{|c|c|c|}
\hline $\begin{array}{l}\text { Factors adversely affecting viability in junior mining } \\
\text { companies }\end{array}$ & Observed chi-square value & P-value \\
\hline High cost of transportation & 11.4090 & $0.000^{* * *}$ \\
\hline Low demand for mining products & 10.3157 & $0.000^{* * *}$ \\
\hline Failure to improve public image & 9.3007 & $0.000 * * *$ \\
\hline Failure to employ enough employees & 8.9401 & $0.003^{*} *$ \\
\hline Lack of liquidity & 8.1516 & $0.004^{* *}$ \\
\hline Lack of sales growth & 8.1035 & $0.044^{*}$ \\
\hline Intense completion from rivals & 5.6560 & $0.017^{*}$ \\
\hline Too much bureaucracy and red tape & 4.8090 & $0.028^{*}$ \\
\hline
\end{tabular}

Note: Significance at ${ }^{\star} \mathrm{P}<0.05 ;{ }^{* *} \mathrm{P}<0.01 ;{ }^{* \star} \mathrm{P}<0.001$ levels of significance. 


\section{DISCUSSION OF RESULTS}

The study has led to the identification of key obstacles to profitability in junior mines. In this regard, the first obstacle is the high cost of transportation. The second obstacle is falling demand for commodity products in local and international markets. The third obstacle is lack of leadership and good corporate governance in the mining sector. There are numerous opportunities for growth in the junior mining industry. However, there is a need for good corporate governance and leadership in the industry. The above three obstacles cannot be addressed by the South African Government alone. Active participation is needed from the private sector in this regard. In order to attract the private sector, tangible economic incentives must be provided to the private sector. Similar findings have been reported in the relevant literature by Booysens (2011), Worku (2016), Buckley and Ghauri (2012).

\section{RECOMMENDATIONS OF STUDY}

It is in order to make appropriate recommendations to junior mines operating in the Witbank region of Mpumalanga Province:

- Junior mines should seek skills based training from the South African Small Enterprise Development Agency (SEDA) as a means of improving the degree of specialised skills their employees possess. Doing so enables junior mines to be operationally fit enough to compete adequately at the local and global markets and be financially viable.

- Junior mines should pursue strategic partnerships and collaborations with well-established mining enterprises with a view to have access to local and global markets.

\section{REFERENCES}

1. Acharya, V. V., Lochstoer, L. A., \& Ramadorai, T. (2013). Limits to arbitrage and hedging: Evidence from commodity markets. Journal of Financial Economics, 109(1), 441-465.

2. Achrya, V., Philippon, T., Richardson, M., \& Roubini, N. (2009). The financial crisis of 2007-2009: causes and remedies. New York: John Wiley \& Sons.

3. Adams, R. B., Mehran, H. (2003). Is corporate governance different for bank holding companies? Federal Reserve Bank of New York Economic Policy Review, 9(1), 123-142.

4. Amit, R., \& Schoemaker, P.J.H. (2013). Strategic Assets and Organizational Rent. Strategic Management Journal, 14(1), 33-46.

5. Anderson, M., Asdemir, O., \& Tripathy, A. (2011). Use of precedent and antecedent information in strategic cost management. Journal of Business Research, 2(1), 21-26.
6. Bagozzi, R. P. (2007). The Legacy of the Technology Acceptance Model and a Proposal for a Paradigm Shift. Journal of the Association for Information Systems, 8(4), 244-254.

7. Barney, J. B. (2012). Firm Resources and Sustained Competitive Advantage. Journal of Management, 17(1), 99-120.

8. Beck, T., \& Demirguc-Kunt, A. (2012). Small and medium-size enterprises: access to finance as a growth constraint. Journal of Banking and Finance, 30(11), 2931-2943.

9. Beetsma, R., Giuliodori, M., De Jong, F., \& Widijanto, D. (2013). Spread the news: the impact of news on the European sovereign bond markets during the crisis. Journal of International Money and Finance, 34(1), 83-101.

10. Benjamin, G., Andreas, B., \& Ramon, K. (2012). Organization from a systemic perspective:
Application of the viable system model to the Swiss Youth Hostel Association. Kybernetes, 39(9-10), 1627-1644.

11. Bharadwaj, A. (2013). A ResourceBased Perspective On Information Technology Capability And Firm Performance: An Empirical Investigation. Mis Quarterly, 24(1), 169-196.

12. Bhatt, G. D., \& Grover, V. (2013). Types Of Information Technology Capabilities And Their Role In Competitive Advantage: An Empirical Study. Journal of Management Information Systems, 22(2), 253-277.

13. Booysens, I. (2011). Are Small, Medium And MicroSized Enterprises Engines Of Innovation? The Reality in South Africa. Science and Public Policy, 38(1), 67-78.

14. Buckley, P. J., \& Ghauri, P. N. (2012). Globalisation, Economic Geography And The Strategy of 
Multinational Enterprises. Journal of International Business Studies, 35(2), 81-98.

15. Cheng, I.-H., Kirilenko, A., \& Xiong, W. (2015). Convective risk flows in commodity futures markets. Review of Finance, 19(1), 1733-1781.

16. Dashwood, H. S. (2014). Sustainable Development and Industry Self-Regulation Developments in the Global Mining Sector. Business \& Society, 53(4), 551-582.

17. Deloitte. (2016). Tracking the trends 2015. The top 10 issues mining companies will face in the coming year. Retrieved from https://www2.deloitte.com/ (accessed on 17.03.2017)

18. Duffie, D. (2010). Presidential address: Asset price dynamics with slow-moving capital. Journal of Finance, 65(1), 1237-1267.

19. Du Plessis, H., \& Van Niekerk, A. (2014). A new GISc framework and competency set for curricula development at South African universities. South African Journal of Geomatics, 3(1), 1-12.

20. Elliot, R., \& Boshoff, C. (2013). The influence of organisation factors in small tourism businesses on the success of internet marketing. Management Dynamics, 14(3), 44-58.

21. Fahy, J. (2013). The resourcebased view of the firm: some stumbling-blocks on the road to understanding sustainable competitive advantage. Journal of European Industrial Training, 21(2), 94-104.

22. Hair, J. F., Black, W. C., Babin, B. J., \& Anderson, R. E. (2010). Multivariate Data Analysis: A Global Perspective. London: Pearson.

23. Henderson, B. J., Pearson, n.d. wang, 1. (2015). New evidence on the financialization of commodity markets. Review of Financial Studies, 28(1), 1285-1311.
24. Henderson, B. J., Pearson, N. D., \& Wang, L. (2014). New evidence on the financialization of commodity markets. Review of Financial Studies, 1(2), 91-102.

25. Henisz, W. J., Dorobantu, S., \& Nartey, L. J. (2014). Spinning gold: The financial returns to stakeholder engagement. Strategic Management Journal, 35(12), 1727-1748.

26. Hosmer, D. W., \& Lemeshow, S. (2013). Applied Logistic Regression. New York: John Wiley and Sons.

27. Katzenbach, J., \& Bromfield, P. (2009). How to cut costs in a recession with help from employees. Strategy and Leadership, 37(3), 9-16.

28. Ladzani, M. W., \& Seeletse, S. M. (2012). Business social responsibility. How are SME's doing in Gauteng, South Africa? Social Responsibility Journal, 8(1), 87-99.

29. Nel, P., Werner, A., Poisat, P., Sono, T., Du Plessis, A., \& Ngalo, O. (2011). Human Resource Management. Cape Town: Oxford University Press.

30. Pienaar, W. J., \& Vogt, J. J. (2013). Business Logistics Management a supply chain perspectives, 3rd edition. London: Oxford University press.

31. Prahalad, C. K., \& Hamel, G. (2014). The core competence of the corporation. Harvard Business Review, 6(1), 79-92.

32. Shank, J. K, Lawler, W. L., \& Carr, L. P. (2015). The profit impact of value chain configuration: Blending strategic cost management and Action-ProfitLinkage (APL) perspective. Advances in Management Accounting, 12(1), 37-58.

33. Sidortsov, R. (2014). Reinventing rules for environmental risk governance in the energy sector. Energy Research \& Social Science, 1(1), 171-182.
34. Sovacool, B. K. (2014). Optimisation of resources. Energy Research \& Social Science, 1(1), 19-27.

35. South African Chamber of Mines. (2016). Facts and Figures 2015. Retrieved from http://www.chamberofmines.org.za/mining-industry/gold (accessed on 17.03.2017).

36. South African National Department of Labour. (2016). Annual report for 2014/2015. Retrieved from http://www. labour.gov.za/DOL/ (accessed on 17.03.2017)

37. South African National Department of Public Service Administration. (2016). White Paper on the Transformation of the Public Service. Retrieved from http://www.dpsa.gov.za/ (accessed on 17.03.2017)

38. Small Enterprise Development Agency. (2016). Annual report for 2015/2016. Retrieved from www.seda.org.za/ (accessed on 17.03.2017).

39. Sovacool, B. K., Sidortsov, R., \& Jones, B. (2013). Energy security, equality, and justice. London: Routledge.

40. Sovacool, B. K., \& Cooper, C. J. (2013). The governance of energy megaprojects: politics, hubris, and energy security. London: Edward Elgar.

41. Spreng, D. (2014).

Transdisciplinary energy research - reflecting the context. Energy Research \& Social Science, 1(1), 65-73.

42. Statistics South Africa. (2016). Facts and figures for 2014/2015. Pretoria: Statistics South Africa.

43. Worku, Z. (2016). The impact of poor quality municipal services on small enterprises. Investment Management \& Financial Innovations, 14(4), 274-279. 